J. Gen. Appl. Microbiol.

Vol. 10, No. 4. 1964.

\title{
CYCLIC CHEMICAL AND MORPHOLOGICAL CHANGES IN NOCARDIA RUBRA
}

\author{
G. E. MICHAELS, N. M. MCCLUNG and R. G. EAGON \\ Department of Bacteriology, University of Georgia \\ Athens, Georgia, USA \\ Received August 3, 1964
}

The cyclic nature of the vegetative growth of members of the genus Nocardia has been well established(1). Nocardia cells normally progress from a filamentous, to a bacillary, and finally to a coccoid stage. Cells of the coccoid stage, if implanted in a fresh medium, will germinate by 2 or more germ tubes to reestablish the filamentous stage (Fig. 2). In the present work the change in amounts of nucleic acid, lipid, protein, and ash was correlated with gross morphological changes during the life cycle of this organism. A high yielding biphasic culturing system is described and the resulting growth curves compared with those of liquid shake cultures.

\section{METHODS}

Organism. The organism used throughout this work was Proactinomyces ruber (Casabó) Bald. (Nocardia rubra), obtained in 1947 from the Centraalbureau voor Schimmelcultures, Baarn, Holland. The culture was maintained at $4^{\circ}$, and transferred every 3 months onto nutrient or BENNETT's agar. The culture coincided with the taxonomic criteria listed in the 7th Edition of Bergey's Manual of Determinative Bacteriology for Nocardia rubra.

Conditions of cultivation. It was found that surface growth on a solid medium did not produce adequate yields for chemical analyses when the growing period was less than $24 \mathrm{hr}$. Liquid shake cultures produced enough early growth, but for incubation periods longer than $32 \mathrm{hr}$ the cultures tended to undergo autolysis, thus insufficient yields resulted. A biphasic system(2), in which $200 \mathrm{ml}$ of modified CzAPEK agar (3), after solidification was overlaid with $100 \mathrm{ml}$ of nutrient broth(3), in $500 \mathrm{ml}$ Erlenmeyer flasks, produced sufficiently high yields. However, Difco CzAPEK agar was too soft to withstand long periods of shaking. An addition of $5 \mathrm{~g}$ of agar per liter to the commercial Czapek agar lent sufficient stability.

The medium was adjusted to $\mathrm{pH} 7.2$, inoculated, and incubated at $31^{\circ}$

1) This investigation was supported in part by grant No. E-2075 from the Institute of Allergy and Infectious Diseases, U.S. Public Health Service and a U.S. Public Health Traineeship (60-329). 
on a rotary shaker. The inoculum was prepared by seeding a flask containing the above medium from a stock culture of $N$. rubra and incubating for $24 \mathrm{hr}$ on a rotary shaker. One $\mathrm{ml}$ of the resulting cell suspension was used for seeding each succeeding flask of medium.

Harvesting of cells. The cells for biochemical analyses were harvested after incubation for the indicated times (Figs. 3 and 4 ) by centrifugation at $18,000 \times g$ for $15 \mathrm{~min}$ in a Spinco refrigerated centrifuge followed by three washings with distilled water. Finally, the cells were dried for $12 \mathrm{hr}$ in vacuo over $\mathrm{P}_{2} \mathrm{O}_{5}$ and stored in a desiccator over calcium chloride at $4^{\circ}$ until analysed. Before analyses, the cell clumps were ground using a mortar and pestle, and redried over $\mathrm{P}_{2} \mathrm{O}_{5}$ in vacuo for $2 \mathrm{hr}$.

Slide and grid preparation. When samples were removed to determine the quantity of growth, simple crystal violet-stained smears were prepared for the light microscope at the same time. The grids for electron microscopy were prepared from $1 \mathrm{ml}$ portions of the remainder of each sample by centrifuging at speeds just sufficient to settle the cells without packing. The supernatant was decanted and the cells resuspended in sterile distilled water, washed, and again settled by centrifugation; this process was repeated three times. A portion of these washed cells was resuspended in sterile distilled water; then a small droplet was placed on each grid using a micropipete and air dried. This was followed by washing the dried suspension on the grids with droplets of sterile distilled water which produced a clean, evenly distributed preparation. After shadow-casting the specimen with platinum-palladium alloy (80/20), they were examined with an R.C.A. EMU-2E electron microscope. Electron micrographs were taken to study the degree of mycelial formation during the growth cycle.

Extraction for nucleic acid estimation. Following the method of Schneider (4) for nucleic acid determination, the acid-soluble phosphorus compounds were extracted from the dried cells with $10 \%$ cold trichloracetic acid (TCA), and the phospholipid fractions removed by boiling in a mixture of alcohol and ether. The nucleic acids were then removed with hot $10 \%$ TCA and water. The method of Burton (5) was used for the colorimetric estimation of the deoxyribonucleic acid (DNA) using the diphenylamine reaction. A standard solution of salmon sperm DNA (Mann Research Laboratories, New York) was prepared for comparison. The color was developed by incubating at $30^{\circ}$ for $18 \mathrm{hr}$. The optical density was then read at $600 \mathrm{~m} \mu$ in a Coleman Jr. spectrophotometer.

The ribonucleic acid (RNA) was determined by using a modification of Bial's $(6)$ original orcinol reaction. An equal volume of concentrated $\mathrm{HCl}$ containing $0.1 \% \mathrm{FeCl}_{3} \cdot 6 \mathrm{H}_{2} \mathrm{O}$ and $0.1 \%$ orcinol (twice recrystallized from benzene) was added to a $0.2 \mathrm{ml}$ portion of the nucleic acid extract. The mixture was then heated for $45 \mathrm{~min}$ in boiling water. A standard solution of yeast RNA (Mann Research Laboratories) and a water blank served as controls, and the optical densities of the solutions were measured at 
$670 \mathrm{~m} \mu$.

Total lipid determination. A modification of the method of THIELE( $(\boldsymbol{y})$ was used to determine the total lipid content of the $N$. rubra cells. A sample of $500 \mathrm{mg}$ of powdered cells was extracted by boiling under reflux for $30 \mathrm{~min}$ with $15 \mathrm{ml}$ of a $3: 1$ methyl alcohol-chloroform mixture. The hot solution was then filtered. The process was repeated a 2 nd and $3 \mathrm{rd}$ time by adding the same volume of the solvent and refluxing for 25 and $60 \mathrm{~min}$ respectively. The resulting filtrate was evaporated almost to dryness in an atmosphere of nitrogen, and the residue was dissolved in a small volume of 1:2 methyl alcohol-chloroform mixture, overlaid with distilled water and left standing in the dark at room temperatures for $24 \mathrm{hr}$. The water layer was removed with a micropipete and the remaining lipid fraction dried and weighed.

Protein estimation. The protein content of the cells was estimated by determining the percentage of nitrogen present in the dry weight of ultrasonically broken cells by the micro-Kjeldahl method (8) then multiplying by the factor 6.25 , a constant derived from the assumption that average proteins contain 16\% nitrogen. The determination was made on a suspension containing $1 \mathrm{mg}$ of cells per $\mathrm{ml}$ of water. The nitrogen content was then determined by comparing the unknown with a Nessler standard based on the response of a solution of ammonium sulfate containing $0.1 \mathrm{mg}$ nitrogen per ml.

Total ash. To find the total ash content of the cells, $250 \mathrm{mg}$ samples of the cells were incinerated at $550^{\circ}$ for $15 \mathrm{~min}$, cooled in a desiccator, and reweighed on an analytical balance. Successive incinerating periods of $15 \mathrm{~min}$ were repeated until a constant weight was obtained.

\section{RESULTS}

Morphological changes during the growth cycle

The sequence of morphological changes in N. rubra was the same in liquid shake-culture and the biphasic system. However, the logarithmic growth period for the biphasic system was $20 \mathrm{hr}$ longer than for the liquid shake-culture method (Fig. 1). Within two to four hours after the biphasic system was first inoculated with ungerminated coccoid Nocardia cells (microcysts), these cells germinated by means of germ tubes (Fig. 2 A, B and $\mathrm{C}$ ). When bacillary cells were present in the inoculum, they germinated by elongation followed by branching. Some microcysts formed more than one germ tube; as many as four were occasionally produced. This multiple germination was responsible for many of the branched clusters of filaments seen in young cultures (Fig. 2D).

After $12 \mathrm{hr}$ of incubation branching decreased, and the filaments became shorter. This trend continued until the bacillary forms predominated after $36 \mathrm{hr}$ of incubation. Nearly all the cells were in the short bacillary to coccoid stage at the end of $48 \mathrm{hr}$ and by $64 \mathrm{hr}$ coccoid cells predominated. 


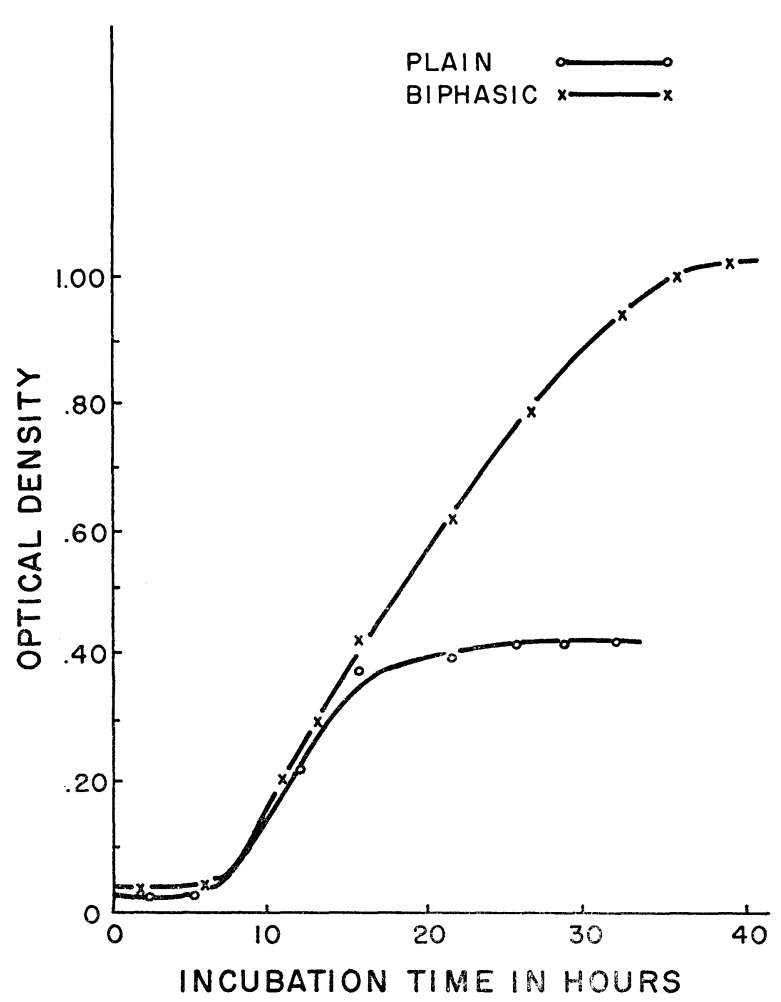

Fig. 1. A comparison of the growth curves for the plain and biphasic incubation systems of Nocardia rubra.

Finally, after $96 \mathrm{hr}$ of incubation a stable coccoid stage predominated. Further incubation did not bring about additional developmental changes; this terminal coccoid or microcyst culture consisted of a mixture of spherical, egg-shaped, and cubical cells (Fig. 2E).

Constitutive chemical changes during the growth cycle

None of constitutive materials assayed maintained a constant level, in terms of percentage of total cell dry weight, throughout the growth cycle.

The DNA fluctuated between 1.5 and $3.0 \%$ of the dry weight with the highest percentage being found in the cells which had been harvested after $24 \mathrm{hr}$ of incubation as shown in Fig. 3. RNA followed a curve similar to DNA. However, RNA fluctuated between 4.0 and $20.1 \%$ of the dry weight; and the peak came after $20 \mathrm{hr}$ of incubation, $4 \mathrm{hr}$ sooner than the DNA peak (Fig. 4).

Unlike DNA and RNA contents, which showed definite peaks, the lipid content steadily rose from $9.5 \%$ of the dry weight of $8 \mathrm{hr}$ cells to $31 \%$ of the $96 \mathrm{hr}$ old cells. The greatest increase in lipid content occurred between the 8 th and $20 \mathrm{th} \mathrm{hr}$ of incubation; after $20 \mathrm{hr}$ the lipid content continued 


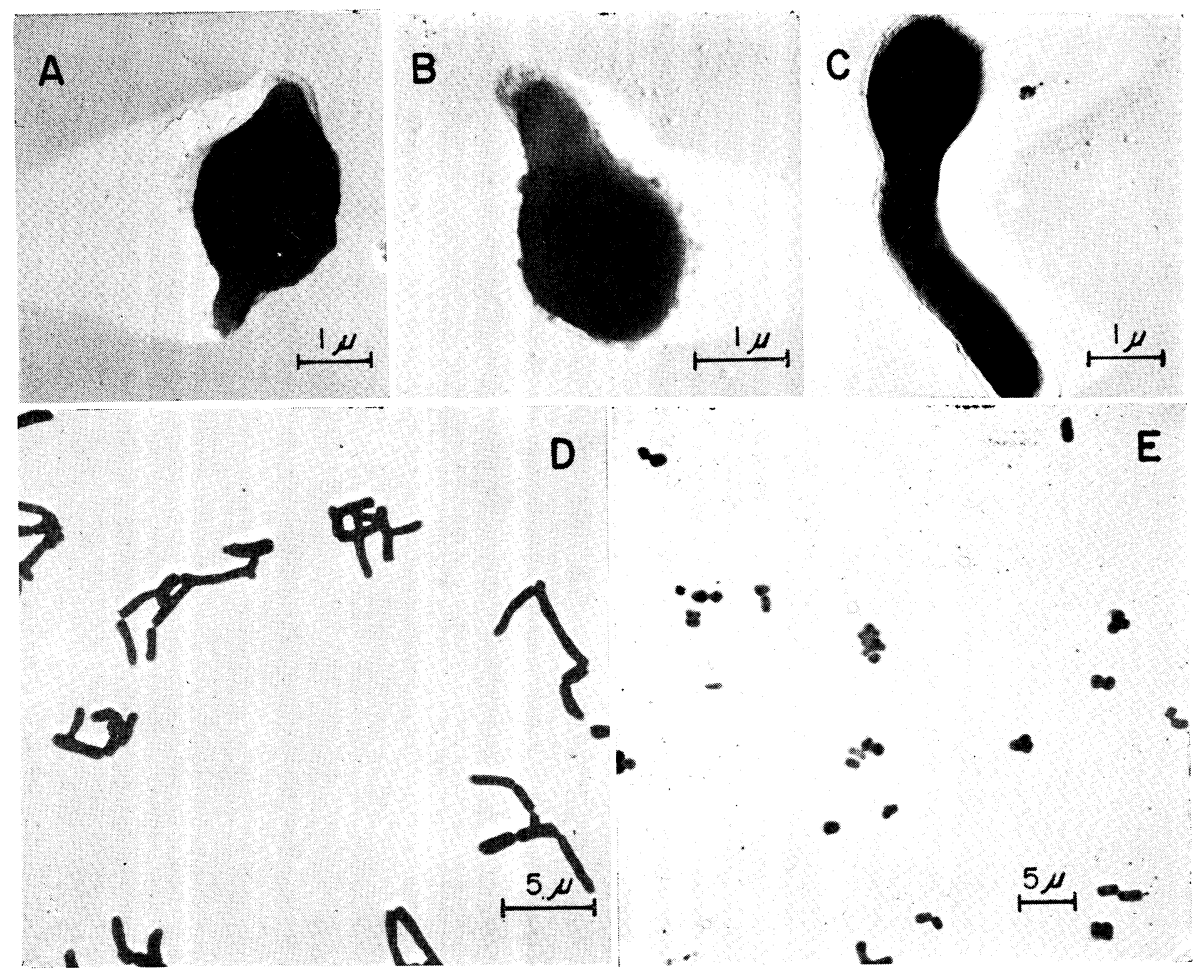

Fig. 2. Electron micrographs of Nocardia rubra shadow-cast with platinumpalladium alloy. A,B,C: germinating $N$. rubra microcysts $\mathrm{D}$ : short filaments and branched $N$. rubra cells after $24 \mathrm{hr}$ of incubation. E: short bacillary to coccoid cells after $48 \mathrm{hr}$ of incubation.

Table 1. Ratios of RNA to DNA of Nocardia rubra cells.

\begin{tabular}{c|c|c|c|}
\hline $\begin{array}{c}\text { Age } \\
\text { (hr) }\end{array}$ & $\begin{array}{c}\text { DNA } \\
(\mathrm{mg} / \mathrm{g})\end{array}$ & $\begin{array}{c}\text { RNA } \\
(\mathrm{mg} / \mathrm{g})\end{array}$ & Ratio $\frac{\text { RNA }}{\text { DNA }}$ \\
\hline 8 & $22^{a}$ & $130^{a}$ & 5.9 \\
12 & 21 & 165 & 7.8 \\
20 & 28 & 201 & 7.1 \\
24 & 30 & 172 & 5.7 \\
36 & 20 & 100 & 5.0 \\
48 & 17 & 90 & 5.2 \\
96 & 15 & 40 & 2.6 \\
\hline
\end{tabular}

a Milligrams of nucleic acids per gram of dry cell weight. 
to increase gradually (Fig. 4).

The protein estimation, as reflected by the nitrogen content, revealed a decrease from about $50 \%$ for the $8 \mathrm{hr}$ cells to $44 \%$ for the $20 \mathrm{hr}$ cells.

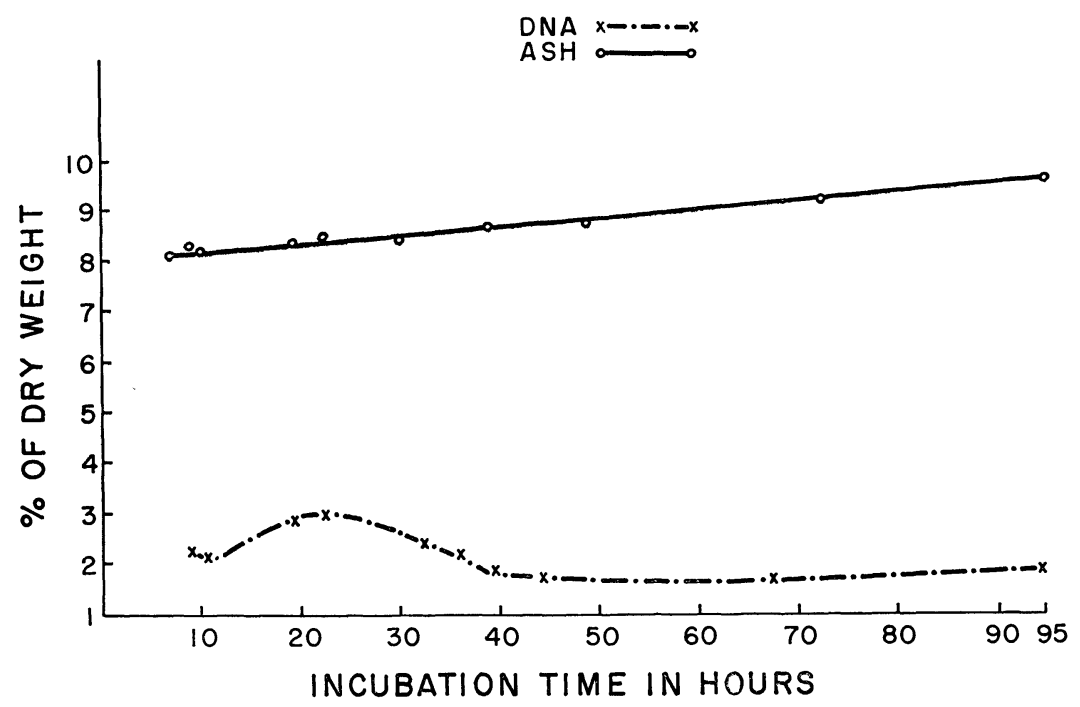

Fig. 3. The effect of incubation time on DNA and ash content in Nocardia rubra.

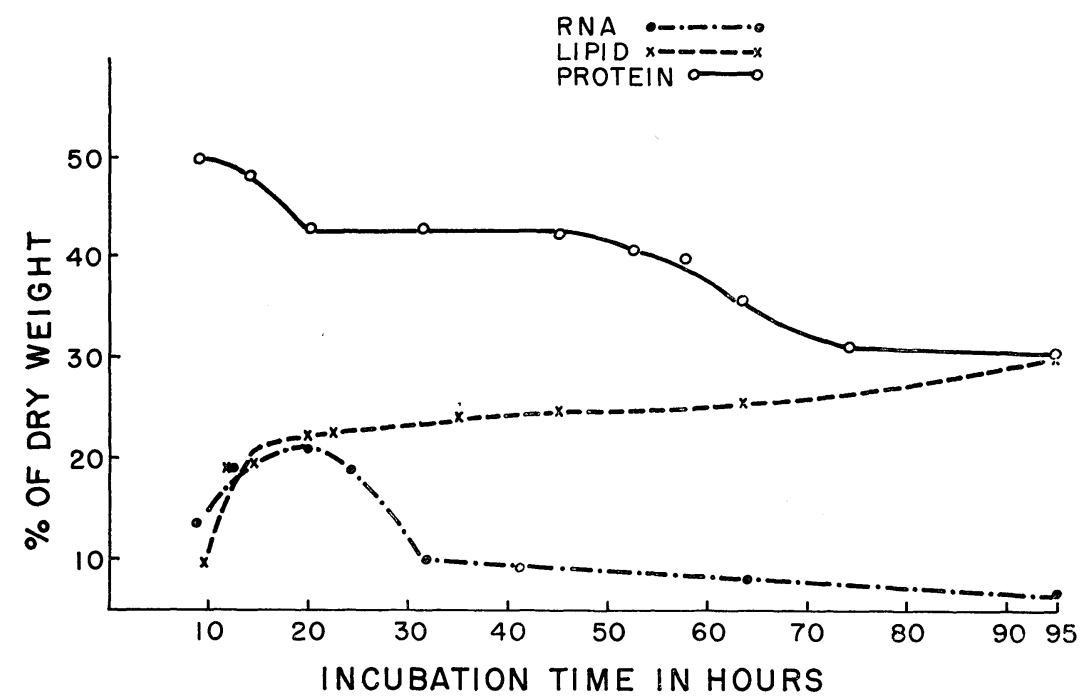

Fig. 4. A comparison of the RNA, lipid, and protein content of Nocardia rubra.

At this point the protein content leveled off at $44 \%$ for a period of about $24 \mathrm{hr}$. After $44 \mathrm{hr}$ of incubation the protein content decreased to a low of $31 \%$ for the $96 \mathrm{hr}$ cells, 
The total ash content steadily increased from $8.3 \%$ to $9.5 \%$ during the $96 \mathrm{hr}$ of incubation in the biphasic system. The rate of increase in total ash content did not fluctuate throughout the observation period.

\section{DISCUSSION}

The morphological progression of cell types in Nocardia spp. has been observed by others $(1,9,10)$; this investigation demonstrated that this morphological progression is also accompanied by physiological constitutive chemical changes characteristic of each stage in the life cycle. The progression of the various stages of the life cycle were the same in both growth systems, but the elongation and fragmentation were extended over a longer logarithmic growth period in the biphasic system (Fig. 1).

The percentages of dry cell mass present as nucleic acids were within the ranges reported for other organisms (11). Both the DNA and RNA contents were highest during the 10 to $30 \mathrm{hr}$ incubation period following the lag phase. This $20 \mathrm{hr}$ incubation period of high nucleic acid content corresponded, as one would expect, to the period of greatest growth activity, the logarithmic phase. When N. rubra cells entered a period of reduced growth and multiplication, the relative amount of nucleic acid steadily decreased; which in turn reflected the decreased biosynthetic activities, especially that of protein synthesis.

The ratios of RNA to DNA indicated that during the lag phase the RNA content was proportionally lower than in the logarithmic phase (Table 1). The ratio of RNA to DNA decreased after the beginning of the logarithmic phase to a low of $2.6 \%$ at the end of $96 \mathrm{hr}$ of incubation. This supports the findings of $\mathrm{S}_{\mathrm{ATO}}(11)$ that the ratios of RNA to DNA decreased with the lapse of time. The high RNA/DNA ratios also corresponded to the period of increased protein synthesis.

Since the cell yield for the 0 to $8 \mathrm{hr}$ incubation periods was not sufficient for analyses, one can only speculate on the nucleic acid fluctuations during that period. But if $N$. rubra does have an early drop in RNA content such as has been reported for Escherichia coli(12) this would account for the fact that the percentage of RNA was rapidly increasing after $8 \mathrm{hr}$ of incubation, but the percentage was still only about equal to that of the original $24 \mathrm{hr}$ old inoculum. If the RNA content had increased at a steady rate during 0 to $8 \mathrm{hr}$ incubation, this value would have been considerably higher than the value for the RNA content of the original inoculum.

The continuous increase in total lipid content (Fig. 4) was not unexpected since the organism was grown in the nutrient-rich biphasic system. The high of $30.8 \%$ lipid content found for this organism was similar to percentages found for some of the mycobacteria. LoNG and CAmpbell (13), for example, found that Mycobacterium tuberculosis, $M$. smegmatis, and $M$. phlei had respectively 22.7, 35.6, and 20.2\% lipid content. Percentages of lipid for other bacteria are somewhat lower(14), 
but the total lipid content of microorganisms is so strongly affected by cultural conditions and age, that any set of figures may be very misleading. If the relatively higher percentages of lipid material is characteristic of all Nocardia species and for Mycobacterium species as well, as some authors have reported, this would suggest the need for a study of the relationship between lipid content and the acid-fastness manifested in many of these organisms. Some of the lipid increase can be accounted for in the increasing carotenoid pigment content of the organism (15).

As the lipid content and, to a lesser extent, the ash content increased, the protein content decreased. Since these data are percentages relative to the total dry weight, the decreasing protein content could be due to either an increase in other cell constituents or to an actual loss of proteinaceous material. As the curve in Fig. 4 shows, the protein content reached a steady state at the end of $20 \mathrm{hr}$ of incubation. This lasted until after $45 \mathrm{hr}$ of incubation, when the protein content again dropped. This steady state of protein content approximately followed the period of highest nucleic acid content. This observation indicated that the organism followed the established relationship between nucleic acid and protein synthesis (16).

By the end of $45 \mathrm{hr}$ incubation, decreased cellular synthesis was reflected by the amount of growth, the nucleic acid content, and the protein content. The cells at this stage were, for the most part, bacillary in form. It appears that this period completes the minimum vegetative growth cycle since these bacillary forms will germinate and repeat the vegetative cycle. Additional incubation beyond $45 \mathrm{hr}$ in the biphasic system produced a somewhat shorter and more coccoid-shaped cell (microcyst), but further striking morphological changes did not occur.

\section{SUMMARY}

The morphological growth cycle of Nocardia rubra was related to cellular composition when the organism was grown in a biphasic system for varying lengths of time up to $96 \mathrm{hr}$. The DNA, RNA, lipid, protein, and ash content were determined. The morphology of the organism progressed from long branched filaments in the lag phase of the growth curve to shorter and shorter filaments with decreasing branching during the logarithmic phase. In the stationary phase the $N$. rubra cells were bacillary, and gradually became coccoid in the declining or death phase.

The DNA percentage of the dry cell weight increased during the logarithmic growth phase from $2.2 \%$ to $3.0 \%$, and then decreased to $1.5 \%$ during the stationary and declining phase. The RNA content was at a maximum of $20.1 \%$ in the middle of the logarithmic phase, declined sharply to $10 \%$ at the end of this phase, and then decreased more slowly to $4.0 \%$ in the declining phase. The lipid content increased rapidly from $9.9 \%$ to $20 \%$ in the early logarithmic period, at which point it leveled off 
and increased more gradually to $30.8 \%$ in the declining phase. The protein percentage of dry cell weight decreased from $50 \%$ to $43 \%$ during the early logarithmic period and remained steady throughout the remainder of the logarithmic and stationary phases, and finally decreased in the declining growth phase to $31 \%$. The ash content increased steadily from $8.2 \%$ to $9.5 \%$ during the incubation period.

\section{REFERENCES}

(1) N. M. McClung: Kansas Acad. Sci., 58, 50 (1955).

(2) E. A. Tyrrell, E. M. Russell, and P. Gerhardt: J. Bacteriol., 75, 1 (1958).

(3) Difco Laboratories: Difco Manual, 9th Ed., Detroit, Michigan, USA (1953).

(4) W.C. Schneider: J. Biol. Chem., 161, 293 (1945).

(5) K. Burton: Biochem. J., 62, 315 (1956).

(6) M. BIAL: Deut. Med. Wochschr., 15, 253 (1902).

(7) O. W. Thiele: Hoppe-Seyler's Z. Physiol, Chem., 311, 136 (1958).

(8) J. Wong: J. Biol. Chem., 55, 431 (1923).

(9) N. M. MCClung: Lloydia, 12, 137 (1949).

(10) S. Watanabe, A. Kumagaya, H. Murooka: J. Gen. Appl. Microbiol., 9, 363 (1963).

(11) H. Sato: Tohoku J. Exp. Med. 55, 53 (1951).

(12) H. E. WADE: Nature, 176, 4476, 130 (1955).

(13) E. R. Long and L. K. CAMPBell: Am. Rev. Tuberc., 6, 636 (1922).

(14) J. R. Porter: Bacterial Chemistry and Physiology, John Wiley \& Sons, Inc., N. Y., 352 (1946).

(15) L. D. Welton: Masters Thesis, University of Kansas, Lawrence, Kansas, USA (1953).

(16) W.D. MCELroy: Cellular Physiology and Biochemistry, Prentice-Hall Inc., Englewood Cliffs, New Jersey, 105-116 (1961). 